\title{
Presenting a Picture of Alaska Native Village Adaptation: A Method of Analysis
}

\author{
Elizaveta Barrett Ristroph
}

Ristroph Law, Planning, and Research, USA

Copyright $\bigcirc 2017$ by authors, all rights reserved. Authors agree that this article remains permanently open access under the terms of the Creative Commons Attribution License 4.0 International License

\begin{abstract}
Alaska is a large state with 229 nationally recognized tribes, known as Alaska Native Villages (ANVs). Efforts to understand ANV climate change adaptation have often been limited to a particular concern (i.e., flooding and erosion) in a particular part of Alaska (i.e., the west coast). My study is the first that I am aware of attempting to identify adaptation actions, strategies and barriers across the entire state of Alaska and recommend ways for laws and institutions to facilitate adaptation. In this article, I explain a distinct method for identifying adaptation actions, strategies, and barriers that draws on literature, community plans, laws, and interviews and conversations with 153 participants (including ANV residents and those that make or influence policy affecting ANVs). Rather than coding particular segments of an interview or plan, I numerically code interviews and plans as a whole, based on themes expressed therein and from the literature. At the same time, I keep track of quotations that help clarify these themes. This method yields a complex picture of ANV adaptation that shows different views of climate change and adaptation strategies among different sources. Preliminary results of the study suggest a need for measures to improve implementation of community-level adaptation actions, rather than perpetuating a system of government-sponsored planning and data collection in narrow areas. Institutional changes need to be incremental in order to gain political support, yet they must be holistic in addressing the many challenges that ANVs face.
\end{abstract}

Keywords Climate Change Adaptation, Alaska Native Village, Indigenous Communities, Community Planning, Hazard Mitigation Planning, Qualitative Content Analysis

\section{Introduction}

Many communities in the United States and around the world are struggling with the impacts of climate change. Indigenous communities face particular challenges because of their attachment to traditional lands and the impacts of colonization [1, 2803], [2, 299]. Among indigenous peoples in the United States, Alaska Native Villages (ANVs) are especially challenged because of the degree of change they are experiencing [3] as well as their lack of control over land and natural resources [4]. In 2003, the Government Accountability Office (GAO) found that flooding and erosion affected $86 \%$ of all ANVs [5]. In 2009, GAO identified 31 ANVs facing imminent flooding and erosion threats, with four villages in need of relocation [6]. A study by the U.S. Army Corps of Engineers [7] identified extreme erosion problems in many of the same villages as those identified by GAO [6].

GAO's works also addressed vulnerabilities related to ANVs' remoteness and lack of jurisdiction over land and natural resources needed for adaptation. The latter relates to the Alaska Native Claims Settlement Act, characterized by the Indian Law and Order Commission $[8,47]$ as "the last gasp of Federal Termination Policy." This unique Act eliminated aboriginal rights to lands and natural resources and created Native corporations to own and manage roughly $10 \%$ of the tribes' former domain. [9] As a result of this Act, ANVs cannot rely on treaty rights to help them adapt.

There is not a coordinated framework to address adaptation at either the national or state level. At the national level, climate change impacts on communities are often addressed in the aftermath of flooding disasters by the Federal Emergency Management Agency (FEMA) under the U.S. Stafford Act [10]. Little funding has been put into proactive programs like FEMA's Pre-Disaster Mitigation Program [11]. The Alaska Governor's Office previously had a Sub-Cabinet on Climate Change, which was preparing an adaptation strategy and providing technical and financial assistance to communities in need of immediate action to address flooding and erosion. But this Sub-Cabinet has gone dormant. As of this writing, nothing has materialized to take its place. Thus, ANVs are limited in legal and institutional remedies at the national and state levels.

Even if such institutions existed, they may not be enough to provide communities with comprehensive adaptation remedies. From the Alaska Department of Fish and Game to the U.S. Department of Housing and Urban Development, 
many agencies would continue to have jurisdiction over various resources needed for adaptation. A new agency would have to cooperate with existing agencies and wade through the potentially conflicting regulations of these agencies. And all agencies must grapple with a landscape and climate that are unpredictable and may differ from past conditions under which their regulations were made $[12,18]$ $[13,29]$.

There is already a great deal of literature on what enables communities other than ANVs to adapt, and what contributes to adaptive capacity. E.g., $[14,5][15,22026]$ $[16,19]$. The definition and measurement of successful adaptation differs depending on the community at issue and the challenges it faces [17] [18]. In this work, I consider adaptation to be actions (including strategies and plans) that provide for the cultural and physical continuity of ANVs.

While much research has focused on how climate change has impacted indigenous communities [2] [19, 509] [20] [21] [22] [23] [24], published research on how they are adapting and building resilience is more limited [18] [25] [26] [27] [28, 32]. Within Alaska, the focus has often been on climate change impacts (particularly in terms of subsistence) and vulnerability more than adaptation [29] [30] [31] [32] [33]. Research describes the historic resilience, adaptive capacity, and self-sufficiency of Alaska Natives [34, 37] [35, 62] [36, 837] [37, 64] and how this has been eroded by colonization, the creation of dependencies on Western goods and services, poverty, and stigma $[2,298][34,37][35,91][38,13][39$, 1353].

Research on ANV adaptation has considered how individuals in Interior and North Slope communities are responding to impacts to their traditional subsistence-based lifeways [34, 95] [35, 91] [36, 839] [39, 1353] [40] [41, 560] $[42,78][43][44,95]$. There is also research documenting the difficulties for west coast ANVs seeking to relocate [45] [46] [47] [48], but this research does not consider ANV relocations that have occurred in recent decades elsewhere in Alaska. Loring, Gerlach, and Penn [49] consider how people in southwestern ANVs are able to maintain aging infrastructure and community services in the face of climate change. Chapin and Cochran [50] conducted a participatory research project aimed at increasing resilience in four ANVs, which highlights the need for ANV self-sufficiency, collaboration between community entities, and regulatory flexibility. But there has been no comprehensive assessment of how ANVs across the entire state are adapting; and few studies have resulted in specific recommendations for changing laws applicable to ANVs. A statewide analysis is needed because, while Alaska consists of diverse geographies, indigenous cultures and traditions, and degrees of development and remoteness, all 229 ANVs are treated alike under the Alaska Native Claims Settlement Act and other legislation affecting adaptation.

The purpose of my research is to explain how ANVs across the state are adapting to and planning for climate change (specifically, flooding, erosion, and subsistence impacts), and how different strategies, laws, and institutions help or hinder these actions. The purpose of this article is to describe a method capable of capturing the diverse views from ANVs and those outside ANVs, as well as relevant literature and laws. My method benefits from the richness of community knowledge ${ }^{1}$ and qualitative analysis, but is also numeric. The "Key Results and Discussion" section of the article is limited to a snapshot of my overall findings, intended to convey a picture of adaptation from many levels and communities. Future articles will explore the implications of these findings and recommend specific adaptation actions and law changes.

\section{Methods}

\subsection{Interviews}

\subsubsection{Interviews with ANV Residents}

Community knowledge and input from ANV citizens is an important piece of my research, since not all ANVs have written, publicly available plans, and existing plans are not necessarily being implemented. Community knowledge can fill gaps in Western science and written records maintained by agencies and researchers [25] [51] [52, 9] [53, 99]. ANV input is critical from a justice standpoint. ANV citizens will be affected by state and federal adaptation policies even if they had a limited role in creating or influencing them. Likewise, ANV citizens are more affected by climate change than the lawmakers and agency representatives who live in urban settings and do not depend on the land for their physical and cultural continuity $[34,21][54,49][55][56$, 476].

I conducted interviews or had conversations with 76 people from 59 ANVs across Alaska. In most cases, there was one participant per community. Cases in which there was more than one participant per community occurred where I felt that an interview had not fully reflected a flooding disaster that had occurred in that community, or where more than one person from the same community volunteered to participate. While some interviews and conversations took place in communities, most were by phone or during conferences regarding climate change and/or Alaska Native policy. ${ }^{2}$

1 By community knowledge, I mean all kinds of traditional, local, and indigenous environmental knowledge that arises from communities, outside the context of Western science [51].

2 These included the Tanana Chiefs Tribal Court Conference, Aug. 4-6, 2016, Fairbanks, Alaska; Aleutians Life Forum, Aug. 17-20, 2016, Unalaska, Alaska; Southeast Environmental Conference, Sep. 20-23, 2016, Ketchikan, Alaska; Arctic Council Senior Arctic Official meeting, Oct. 4-6, 2016, Portland, Maine; Alaska Federation of Natives, Oct. 20-22, 2016, Fairbanks, Alaska; Alaska Tribal Conference on Environmental Management, Oct. 26, 2016, Anchorage, Alaska; Tanana Chiefs Tribal Government Symposium, Nov. 15-17, 2016, Fairbanks, Alaska; Bureau of Indian Affairs Providers Conference, Nov. 28-Dec. 1, 2016, Anchorage, Alaska; Symposium on Climate Change Migration and Relocation, Honolulu, Hawaii, Dec. 13-14, 2016; Norton Sound Climate Change Adaptation Workshop, Jan. 24, 2017; Alaska Forum on the Environment, Feb. 6-10, 2017. 
I initially recruited participants by sending information on my research to the tribal administrators of each of the 179 inhabited ANVs identified by GAO [5] as affected by flooding and erosion and each of the regional tribal non-profit entities in Alaska. Only nine of these tribal administrators responded with a specific recommendation for someone to interview (though in several cases I was unable to interview this person). I called other tribal administrators and regional tribal organizations for recommendations on interviewees. I also conducted interviews and had conversations ${ }^{3}$ with ANV residents already known to me with knowledge about climate change, and with ANV residents I met at conferences (whether or not they were from the communities identified by GAO). This method of recruitment is not unlike that of Huntington [57, 1217] (research with Alaska subsistence hunters) and Loring et al [46] (research on rural Alaska climate change adaptation).

I continued interviewees and conversations until I felt that I had a sample representing the diversity of ANVs across Alaska, and I was not getting any new information. There are similarities across all Alaska Native groups (i.e., the importance of salmon and other subsistence resources), particularly communities in the same region (i.e., the North Slope of Alaska). But there are also unique "subcultures" [58]. My participants included people from communities that differed in terms of ethnicity (type of Alaska Native and percentage of Alaska Native residents relative to non-Native residents); geography (riverine or coastal; Arctic, Interior, West Coast, Aleutians, South Central, and Southeast); connection to Alaska's road system; political system (presence of incorporated city, location within an incorporated borough (county-level government)); wealth; experience with flooding and erosion disaster declarations; and experience with planning. I gathered demographic information on each community to reflect these differences.

My aim was not to get a random sample, but to use purposive sampling to illustrate adaptation actions across the entire state of Alaska [59, 234-35] [60,75] [61, 365] [62, 447] $[63,318]$. This is important given the heterogeneity of communities and the ultimate goal of developing policies with state-wide applicability [64, 2]. My desire to focus on many communities rather than a handful limited my ability to conduct a more participatory, decolonizing form of research, in which ANVs would set the research objectives and control the dissemination of results [65]. In an effort to make the research more useful and less intrusive for ANVs, I vetted draft questions with Alaska Native individuals from three different regions of Alaska [65, 141].

As recommended by Huntington [55], I had semi-structured interviews with ANV participants. Given the exploratory, descriptive nature of the study, it was important to avoid strict adhesion to a single questionnaire $[66,35]$. Interviewees differed significantly in their expertise

\footnotetext{
${ }^{3}$ The method for these conversations is described in Section 2.2.
}

and what areas they wanted to focus on $[62,152]$. Some interviewees (often elders) responded to my questions with their own narratives that were not directly relevant to the questions from a Western point of view, although the responses were still informative. These interviews were similar to the "testimonial" or "story-telling" approach described by Smith $[65,145]$.

I created a set of field notes for each interview based on the recorded transcript (or based on notes taken when I did not have permission to record) $[67,388]$. I used the questionnaire as a "form" to organize the field notes. Most interviews left some questions unanswered, and some generated new themes, which I recorded at the top of the notes.

\subsubsection{Interviews with those outside ANVs}

Interviews with people outside ANVs who may have observed outcomes of adaptation actions provided a different viewpoint from that of ANV representatives. This disparity of views can be an adaptation barrier in itself [34, 15] [68]. At the same time, the different voices helped to flesh out the obstacles faced by both ANVs and decision-makers $[42,76]$ [69]. Where there is agreement on barriers and facilitators to adaptation, solutions may be more feasible to implement $[70,96][71,58]$.

I had interviews or conversations with 77 individuals associated with entities outside of ANVs, including state and federal agencies working on issues related to flooding, erosion, disasters wildlife management, hunting, and Native issues; Alaska Native non-profit organizations; members of the Alaska legislature and their staff; U.S. Congressional staff members; and researchers, planners, and lawyers working with ANVs.

As with community leaders, I selected participants purposively. I started with representatives from the agencies I had preliminarily identified as playing a role in ANV adaptation to flooding, erosion, and subsistence impacts. I identified additional interviewees using a "snowball" technique of getting recommendations from previous interviewees, until I had a sufficiently diverse sample of representatives from agencies with adaptation roles see [61, 367] [72, 152] [73, 95]. I selected researchers, planners, and lawyer from those who have worked with ANVs on planning, adaptation, and natural resource management. I selected legislators from those who have introduced bills relevant to climate change and adaptation as well as those that have made media statements against such bills.

I ensured diversity by picking participants that differed in terms of race (i.e., Native or non-Native); experience working in and with ANVs; profession; agency or organizational affiliation; attitudes toward climate change; and attitudes of support for ANV assistance.

As with community leaders, interviews were semi-structured, loosely following a questionnaire. Since interviewees had different knowledge sets (ranging from disaster management to wildlife management to legislation), 
I only asked questions appropriate to the interviewee's field. I created a summary of each interview based on the recorded transcript (or based on notes taken during the interview when I did not have permission to record). I used the questionnaire as a "form" to organize the summary, with newly generated themes or information recorded at the top of the form.

\subsection{Field Observation/Informal Conversations}

I used field observation and conversations to supplement my interviews [60, 75] [67, 384], particularly in situations where I was not able to get a formal interview. Observation took place in the form of informal conversations (1) by telephone with a tribal office staff member when trying to identify a tribal member who might be willing to do an interview; (2) by telephone with researchers and agency officials sharing ideas about relocation and other themes; and (3) during conferences and workshops catered toward tribal representatives and advocates with sessions related to climate change and/or Alaska Native policy. ${ }^{4}$ In total, there were 23 such conversations with ANV participants and 16 with those from other entities. These conversations enabled me to develop positive relationships with key informants, stakeholders, and gatekeepers, and to verify or vet information and ideas gained during interviews [74, 16]. Casual conversations were a more comfortable form of interaction for some Alaska Natives who may have had negative experiences with past research $[65,1][67,354]$. Also, they allowed for personalized inquiries with people who had particular knowledge on specific aspects of adaptation strategies and obstacles [59, 342-43].

Field observation usually takes place in the participants' natural setting [59, 262] [74, 16]. Most of my conversations did not occur while I was physically present in villages where adaptations are occurring. Yet since much of the adaptation process involves building social capital with people in power and navigating the Western system $[34,15]$ $[72,112]$, the medium of a conference and workshop with Native and Western participants concerned about adaptation is an important setting. Likewise, many decisions about adaptation are made in office settings, influenced by phone calls, rather than out on the landscape. Thus, I was able to conduct some field observations even while not physically present in all of the villages.

Consistent with guidelines in Mack et al [74, 16-19], I

4 These included the Tanana Chiefs Tribal Court Conference, Aug. 4-6, 2016, Fairbanks, Alaska; Aleutians Life Forum, Aug. 17-20, 2016, Unalaska, Alaska; Southeast Environmental Conference, Sep. 20-23, 2016, Ketchikan, Alaska; Arctic Council Senior Arctic Official meeting, Oct. 4-6, 2016, Portland, Maine; Alaska Federation of Natives, Oct. 20-22, 2016, Fairbanks, Alaska; Alaska Tribal Conference on Environmental Management, Oct. 26, 2016, Anchorage, Alaska; Tanana Chiefs Tribal Government Symposium, Nov. 15-17, 2016, Fairbanks, Alaska; Bureau of Indian Affairs Providers Conference, Nov. 28-Dec. 1, 2016, Anchorage, Alaska; Symposium on Climate Change Migration and Relocation, Honolulu, Hawaii, Dec. 13-14, 2016; Norton Sound Climate Change Adaptation Workshop, Jan. 24, 2017; Alaska Forum on the Environment, Feb. 6-10, 2017. identified myself and the purpose of my research in all of these conversations. I wrote notes about each substantive conversation (i.e., one that answered my research and interview questions) during or as soon as possible after they took place. I then organized each summary according to the questions used for interview participants, although many conversations only responding to a few questions and covered themes outside of my initial questions [59, 343].

\subsection{Review of Community Plans}

I reviewed hazard mitigation plans (HMPs) (required by FEMA for certain kinds of disaster assistance) and other plans for the 59 ANVs from which participants were drawn. Initially, I aimed to compare adaptation strategies described in each community's plans with those identified by the interviewee from that community. During interviews, I realized that interviewees often had limited awareness of the plans, and that plans often did not play a significant role in community adaptation. I decided to use the plans to show adaptations and hazard mitigation measures that have been considered (but not necessarily implemented) by communities, and to demonstrate the gaps between communities and their plans. I created a spreadsheet showing what publicly available plans each selected ANV had, ${ }^{5}$ the years of the plans, whether the plans were ratified by the tribal council or another entity, and which categories of adaptation actions and policies each plan contains. Coding for adaptation actions and policies followed a process similar to interview coding, discussed in further detail in the next section.

\subsection{Analysis}

\subsubsection{Interviews and Conversations}

I used what I call "numeric qualitative content analysis" to analyze interview and conversation summaries. Generally speaking, content analysis refers to "any qualitative data reduction and sense-making effort that takes a volume of qualitative material and attempts to identify core consistencies and meanings" [59, 453]. Qualitative content analysis is a relatively new framework without a well-established analysis procedure [75, 17]. Like grounded theory, it involves identifying and coding themes and patterns. Unlike grounded theory, which is mostly inductive, qualitative content analysis allows the researcher to use a combination of both inductive and deductive approaches in data analysis $[75,4]$. The researcher can reduce data into meaningful categories by limiting the analysis to what is relevant to research questions $[75,5]$.

Coding themes can arise inductively from data collected, or deductively from a prior theoretical understanding, observation, or common sense $[61,55,266]$. There are

5 By publicly available, I mean plans submitted to the Alaska Division of Community and Regional Affairs and posted on this agency's website, or plans readily available through an Internet search. 
"many recipes for arriving at a preliminary set of themes" $[61,56]$. As recommended by Miles and Huberman $[66,58]$, I started creating codes deductively and "etically" (from the researcher's point of view) with themes already identified in the relevant literature, on which I based my interview questions (i.e., whether the community has a plan, whether it has a working relationship with higher levels of government) [67, 402] [76, 781]. This emphasis on coding with "theory-related material" $[61,62]$ contrasts with the grounded theory approach, where categories and codes are generated after data is collected and reviewed $[66,58]$. The aim of my coding was to convert open-ended responses into categories of adaptation actions, policies, barriers, and remedies.

Some new themes (including "emic" themes from the participants' points of view) emerged inductively as I conducted and reviewed more and more interviews, while some of the initial "etic" themes became insignificant [61, $56][63,150][66,61]$. Thus, I revised the codes over time $[67,404][77,831][78,276]$. This iterative coding process is in itself a form of analysis [66, 56].

Rather than coding particular statements, I coded each interview or conversation as a whole based on whether statements made therein corresponded to any of my themes. I tracked the coding using both a spreadsheet and a document that corresponded to all of the column headings within my spreadsheet. This resulted in a "case-by-variable matrix" where each row corresponds to one participant or "case" and each column corresponds to a theme or "variable" $[61,290]$. Variables include coded themes as well as (a) background information gathered on participants' villages from census information (i.e., average income, geographic region, flood declarations, existence of hazard mitigation plan); (b) personal information on participants (i.e., gender and approximate age). I often had two layers of themes. For example, under the larger theme of "community adaptations," I had sub-themes with specific strategies for flood management, subsistence, and other areas. Each cell of the spreadsheet contains a zero if the participant did not discuss the theme represented in the given column. For some themes, there is simply a " 1 " if the theme was discussed. For other themes, I had different numbers to represent different responses. For example, under the sub-theme of flood management, I had codes from 1 to 11 representing different flood management strategies. An excerpt of the spreadsheet is shown in Figure 1.

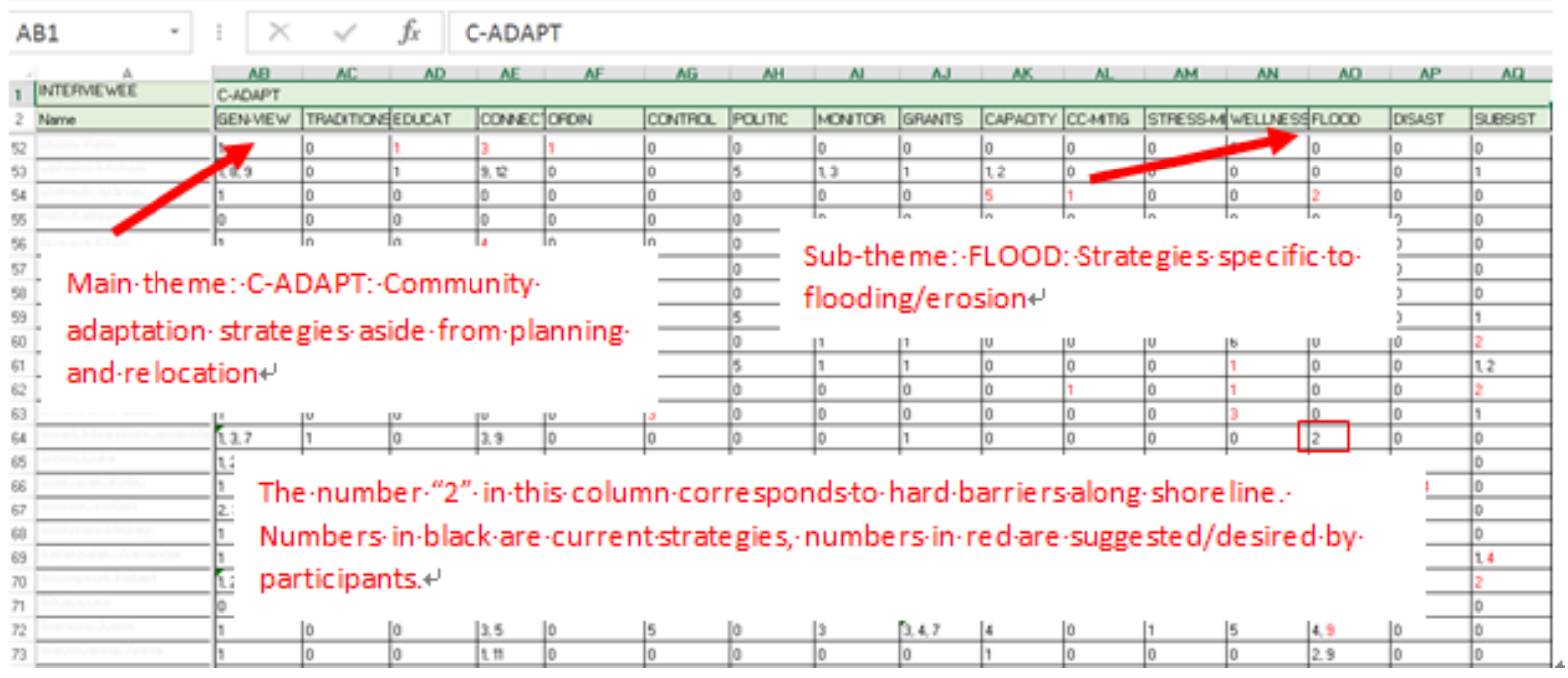

Figure 1. Spreadsheet used in analysis of participant interviews and conversations 

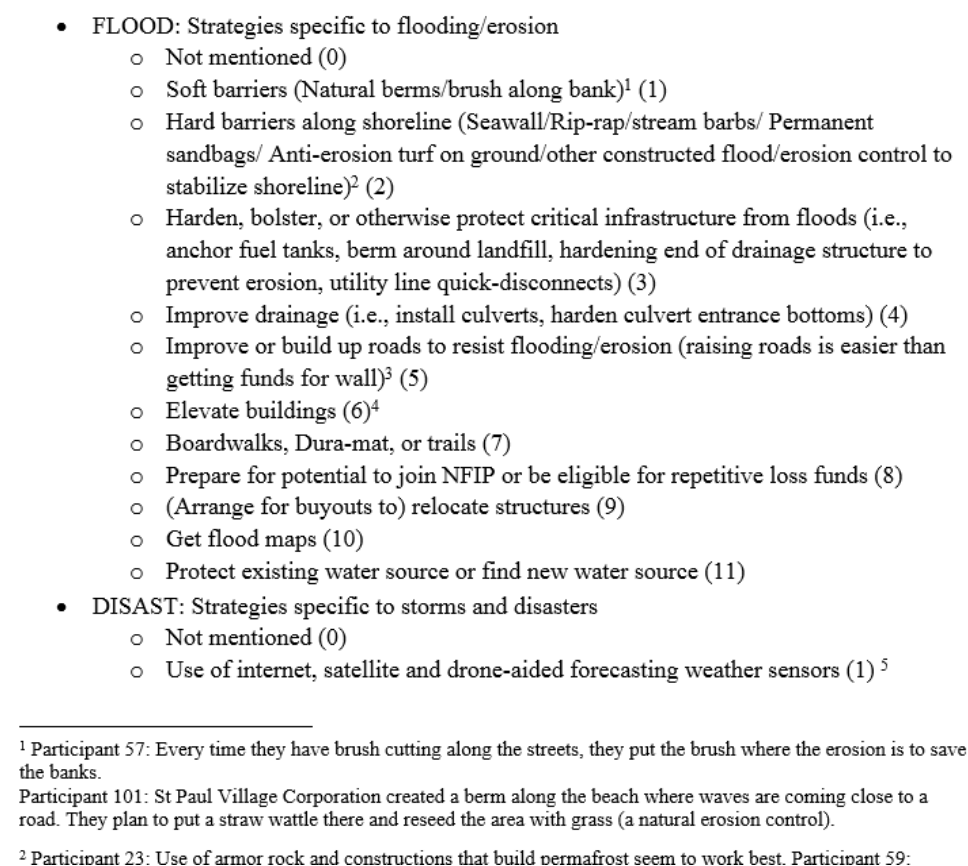

Figure 2. Document used to keep track of spreadsheet themes and preserve participant quotes and insights

Using a spreadsheet limits the ability to include participant quotes or point out nuances in responses. To do this, I kept a Word document with the themes and sub-themes in outline form. I used footnotes to attach quotes and my own analysis to a given sub-theme. Figure 2 shows a portion of this document that corresponds to the spreadsheet sections shown in Figure 1.

What distinguishes my method from other forms of qualitative analysis is the ability to view results numerically while preserving rich insights and quotes provided by participants.

The spreadsheet-document combination allowed me to clearly display which participants said what, and to tally the number of similar responses across participants. Thus, it is more precise than standard qualitative analysis software and better at showing trends. It is also more streamlined than standard software, since the document only includes participant statements that distinctly capture a position or flesh out nuances. Numbers take the place of statements that are short and similar.

My aim was not so much to generate quantitative results, but to find patterns, identify the most important data, and determine whether generalization across interviewees would be appropriate for any theme $[63,71][66,253]$. The differences in the questions answered by different participants (despite starting out with the same questionnaire for the two groups of interviewees) limited the ability to quantitatively compare responses between different participants. Given this limitation and the subjectivity of my coding, I decided that using inferential statistics was not appropriate [61, 288] [66] [80]. Where a particular theme was discussed by less than 15 participants (approximately $10 \%$ of all participants), I put less emphasis on the response.
(See Bertaux [80, 35], suggesting that fifteen is the smallest acceptable sample.) Where 15 or more participants discussed a theme, I focused on how many stated a particular view on that theme (i.e., in support of a policy) and whether those with this view were Native or based in ANVs.

I used a separate spreadsheet to analyze community plans for the 59 ANVs from which participants came. This included 43 HMPs and community land use or economic development plans made within the last 20 years for 35 ANVs. Each row corresponded to an ANV. Columns corresponded to information about the plans for each ANV, such as the year of the latest hazard mitigation plan. I included columns for climate-related hazards and for hazard mitigation or adaptation strategies. The arrangement of these columns mirrored that of the spreadsheet for the participants, although the hazards and strategies proposed in plans typically differed from those raised by participants.

\subsubsection{Identification of Barriers, Facilitators, Institutions, and Laws}

As an additional method of analysis, I made three charts based on information from interviews and conversations and my review of laws and literature. The first chart categorized adaptation needs by topic (i.e., need for coordination among agencies with jurisdiction over adaptation resources). For each topic, I identified actions that help or hinder adaptation at the community level as well as the state/national level. The chart (an excerpt of which is shown in Figure 3) differentiates between current actions and proposed actions (shown in red). Constructing the chart enabled me to match barriers with potential solutions/facilitators.

The second chart (an excerpt of which is shown in Figure 4) 
expanded on the first chart by identifying specific laws that should and could be changed to facilitate adaptation. In the process of identifying relevant laws to change, I found that some laws already allow actions that participants thought would require a law change. For example, some participants suggested a need for a law allowing the federal government to trade federal land with an ANV in order to facilitate relocation. This law already exists. [82]

\begin{tabular}{|c|c|c|c|c|c|}
\hline & \multirow[t]{2}{*}{ Need } & \multicolumn{2}{|c|}{ Community Level } & \multicolumn{2}{|c|}{ Outside Government } \\
\hline & & Hinders & Helps & Hinders & Helps \\
\hline $\begin{array}{l}z \\
\text { o } \\
\frac{1}{1} \\
\text { 㟧 } \\
\text { O } \\
8\end{array}$ & $\begin{array}{l}\text { Cooperation/ } \\
\text { agreement } \\
\text { within } \\
\text { community }\end{array}$ & $\begin{array}{l}\text { - Lack of consensus } \\
\text { between different } \\
\text { community entities on } \\
\text { issues such as } \\
\text { relocation } \\
\text { - Fear of speaking } \\
\text { out/conflict. } \\
\text { Agreement by } \\
\text { consensus rather than } \\
\text { majority vote is often } \\
\text { customary but means } \\
\text { that one person can } \\
\text { derail a plan supported } \\
\text { by everyone else }\end{array}$ & $\begin{array}{l}\text { - Foster connections and } \\
\text { improve communication and } \\
\text { discuss problems through } \\
\text { regular meetings, preferably } \\
\text { with food (e.g., Nenana's } \\
\text { "Community Safety and } \\
\text { Village Pride" - quarterly } \\
\text { meetings with all village } \\
\text { entities) } \\
\text { - Activities that build culture } \\
\text { and spirituality (such as } \\
\text { language learning) } \\
\text { - Change Native corporation } \\
\text { articles of incorporation to } \\
\text { make tribal membership } \\
\text { more consistent with } \\
\text { cooperation }\end{array}$ & $\begin{array}{l}\text { - F: ANCSA created } \\
\text { separation by removing land } \\
\text { from tribes and giving it to } \\
\text { corporations whose } \\
\text { shareholders may not live in } \\
\text { community } \\
\text { - Presence of incorporated } \\
\text { city is a third entity that may } \\
\text { increase opportunities for } \\
\text { disagreement } \\
\text { - Agencies stop working with } \\
\text { communities when there is } \\
\text { intra-community } \\
\text { disagreement }\end{array}$ & $\begin{array}{l}\text { - S\&.F: Continue to meet with different } \\
\text { entities/factions of community to } \\
\text { provide them with information } \\
\text { - Agencies have contributed to programs } \\
\text { that bring communities together } \\
\text { (culture camp) } \\
\text { - Where public meetings are impractical } \\
\text { due to tension or other reasons, } \\
\text { conduct community surveys/interviews } \\
\text { (e.g., Alatna Comprehensive Plan 1995) } \\
\text {-Ask communities if they are interested } \\
\text { in mediation by mutually selected third } \\
\text { party; budget for this as part of } \\
\text { outreach. }\end{array}$ \\
\hline 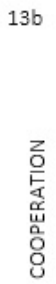 & $\begin{array}{l}\text { Community } \\
\text { leadership }\end{array}$ & $\begin{array}{l}\text { - Lack of initiative to } \\
\text { serve as leaders } \\
\text { - Leaders might not be } \\
\text { trained in leadership } \\
\text { - No pay for tribal chiefs } \\
\text { - Leadership is "diluted" } \\
\text { by presence of } \\
\text { multiple entities. }\end{array}$ & $\begin{array}{l}\text { - Send youth to leadership } \\
\text { programs sponsored by } \\
\text { outside entities } \\
\text { - Incorporate leadership into } \\
\text { culture camp } \\
\text { - Seek ways to raise tribal } \\
\text { revenue }\end{array}$ & $\begin{array}{l}\text { - F: BIA has a limited budget } \\
\text { to support tribes and does } \\
\text { not focus on programs that } \\
\text { would foster tribal economic } \\
\text { development }\end{array}$ & \\
\hline
\end{tabular}

Figure 3. Chart of adaptation barriers and facilitators and community level and state/national level

\section{Feasibility guide:}

Relatively easy to change/likely to pass (low-hanging fruit)

Not so easy to change or unlikely to occur under current administration as of 2017

Difficult to change or unlikely without extensive lobbying by coalition of stakeholders.

Change is more likely to occur when it is specifically articulated, limited to a single statute, and has the potential to help people beyond ANVs (at the federal level, it would need to help people outside of Alaska). Change that is cross-cutting, expensive, and could negatively impact non-ANV stakeholders is unlikely.

\begin{tabular}{|l|l|l|l|l|}
\hline $\begin{array}{l}\text { Row/ } \\
\text { Row from } \\
\text { Adapt. Cht }\end{array}$ & Need & Relevant Law & Actor & Proposed Action \\
\hline A/1 & $\begin{array}{l}\text { Recognition of climate change as } \\
\text { problem for government and } \\
\text { communities to address }\end{array}$ & $\begin{array}{l}\text { EO 13653 (2015) (revoked by } \\
\text { EO 13783 (2017) }\end{array}$ & President & $\begin{array}{l}\text { Re-implement EO 13653, which required agencies to } \\
\text { reform policies that may increase the vulnerability of } \\
\text { communities to climate change related risks and to } \\
\text { inventory their proposed and completed policy changes } \\
\text { aimed at increasing community resilience }\end{array}$ \\
\hline B/4 & $\begin{array}{l}\text { Motivation at all levels to address } \\
\text { climate change adaptation, } \\
\text { especially when there are many } \\
\text { other problems: demonstration to } \\
\text { F government and ANVs that S } \\
\text { government is doing what it can } \\
\text { within its means }\end{array}$ & $\begin{array}{l}\text { AAO 238 (establishing AK } \\
\text { Climate Change Sub-Cabinet } \\
\text { preparation and } \\
\text { implementation of climate } \\
\text { change strategy) } \\
\text { HB 173 (2017, not passed), } \\
\text { "An Act establishing the } \\
\text { Alaska Climate Change } \\
\text { Response Commission" }\end{array}$ & $\begin{array}{l}\text { Governor or S S } \\
\text { Leglature }\end{array}$ & $\begin{array}{l}\text { (Re)establish entity to assist ANVs with climate change } \\
\text { agency. It should be something that can coordinate } \\
\text { resources and knowledge of other state and federal } \\
\text { agencies (e.g., Climate Change Sub-Cabinet IAWG). } \\
\text { A low budget version of this could simply provide for a } \\
\text { climate change "ombudsman" in the Governor's Office or } \\
\text { DCRA that can answer questions and provide guidance } \\
\text { (especially where projects are subject to multiple sets of } \\
\text { conflicting regulations) and identify points of contact for } \\
\text { climate change issues within each state agency. }\end{array}$ \\
\hline
\end{tabular}

Figure 4. Chart of laws to change 


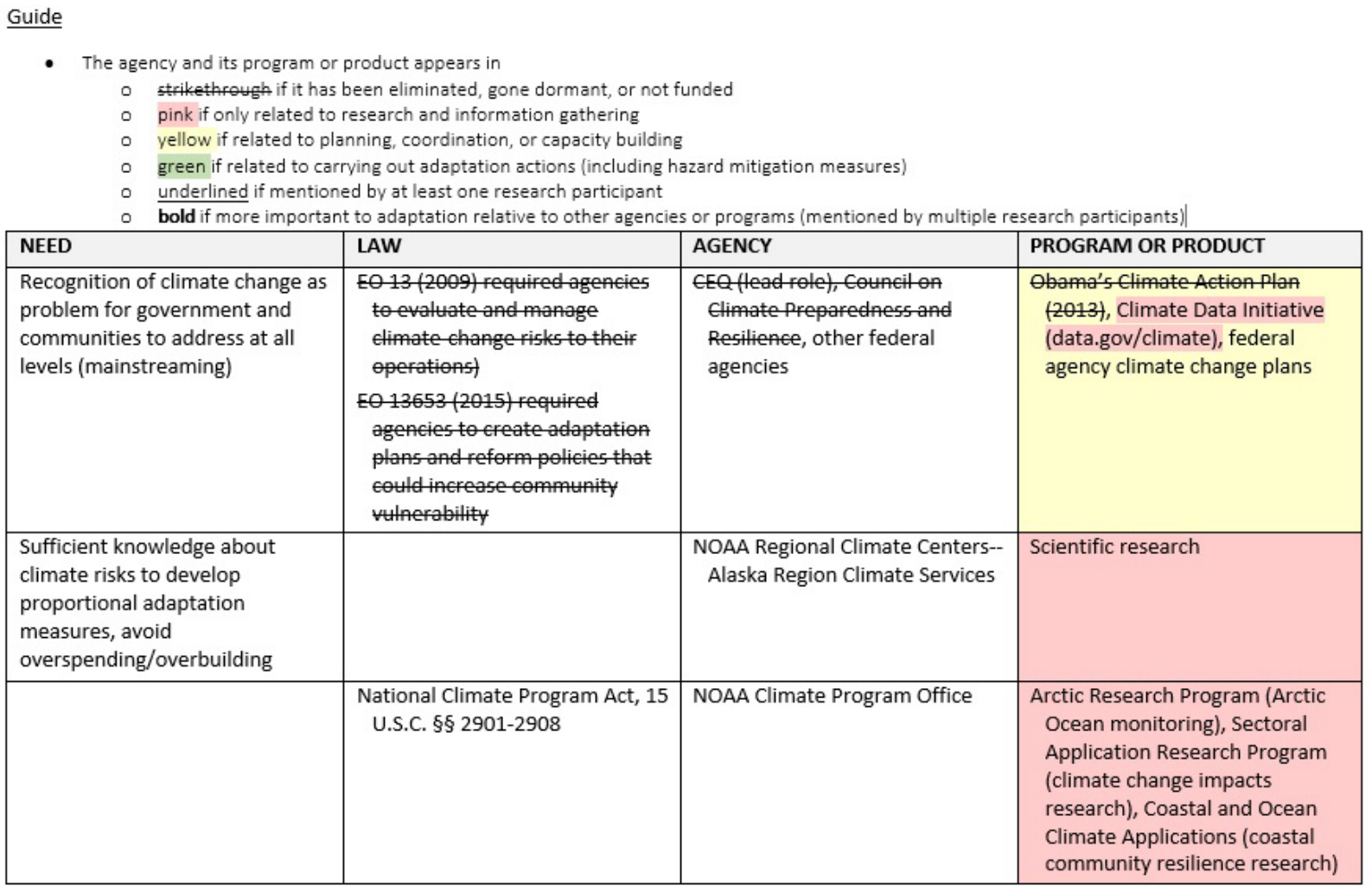

Figure 5. Key agencies, laws, and programs for ANV adaptation

The third chart (an excerpt of which is shown in Figure 5) identified agencies and laws relevant to climate change adaptation for ANVs in terms of flooding, erosion, and subsistence impacts. The process of identifying key agencies and programs demonstrated the disproportionate amount of agencies and resources dedicated to research and planning compared to implementation of adaptation actions. It also demonstrated the plethora of agencies, laws, and programs relevant to adaptation in Alaska, including many that I (and likely most ANV residents) had never heard of.

\subsection{Quality Control}

To control the quality of interviews and conversations with ANV participants, I followed guidelines suggested by Henry Huntington (personal communication 10/14/2015) for obtaining and using community knowledge: the emphasis should not be on whether it is obtained in a consistent manner, but whether (1) reporting is accurate without misinterpretation or cross-cultural miscommunication; and (2) information was obtained from a person who represents the community and is an expert.

I provided each participant (community leaders as well as outsiders) with an interview summary and ask for confirmation $[63,273]$. Many participants did not respond, while 16 confirmed the summaries and 42 offered minor edits. After compiling the chart on adaptation facilitators and barriers, I sought additional input from key participants.
I initially planned to triangulate village plans with participant summaries, but plans seemed to be so aspirational and disconnected from participants' experience that this triangulation was not effective. I also thought that the participation of multiple participants from the same or nearby villages would help triangulate observations about climate change impacts and adaptations, but individual participants (unless interviewed together) tended to focus on their own families' experiences and perspectives. This led to different observations by participants in the same or nearby villages. Still, there were no notable inconsistencies regarding observations on climate change impacts and existing adaptation actions.

\section{Key Results and Discussion}

A single article is insufficient to describe all of the results and implications of such a large study. This section briefly highlights some of the more notable findings regarding adaptation strategies and efforts to assist from those outside ANVs. On some levels, efforts to facilitate adaptation are too narrowly focused - a more holistic approach is needed. On other levels, actions by supporters of ANV adaptation are much broader or greater than what would be most useful for ANVs, and/or lack political will to be implemented. Thus, there is a need for incremental changes that are feasible to implement. 


\subsection{How Participants Perceive Climate Change and Government Role}

Most ANV participants and some outside of ANVs (a total of 97 participants) described the types of climate change they had experienced. ANV participants often focused on changes to species important to subsistence: 25 described reductions in important species and 36 mentioned that animals now appear at different times and different places. Thirty-three noted that climate change made subsistence more difficult and less safe. Other common concerns were warmer weather $(\mathrm{n}=23)$, melting permafrost $(\mathrm{n}=23)$, disasters $(\mathrm{n}=18)$, and more flooding $(\mathrm{n}=17)$. The climate change impacts described by participants differ significantly from the climate-related natural hazards identified in hazard mitigation plans (HMPs), which are supposed to address natural hazards that could impact communities. HMPs often devote no more than a couple of lines to climate change. Only three of the HMPs I reviewed profiled climate change as a natural hazard. Thirty-five HMPs profiled wildfire as a hazard, yet only one participant referred to impacts from wildfires. This shows the disconnect between HMPs and the community experience.

The vast majority of participants saw climate change as a problem. Only four ANV participants suggested otherwise. Ninety-four (36 in ANVs and 58 outside participants) saw a role for government in addressing climate change impacts. No one directly said that government should not assist with climate change adaptation, though some ANVs participants wanted to avoid further outside interference with their communities. Although I did not ask about the government role in mitigating sources of climate change, 22 participants (13 from ANVs) called for government efforts to reduce fossil fuel emissions and/or promote renewable energy.

\subsection{How ANVs are Adapting}

There are different levels of adaptation depending on the community and the type of climate change impact. In most villages, adaptation to subsistence impacts continues to occur as it always has, at the individual and family level. Forty-six participants referred to individual and family level subsistence adaptations, compared with only 23 people mentioning community-level strategies for subsistence and food security (i.e., seeking to co-manage hunting with agencies). Hunters and fishers adjust their practices and try to adhere to complex laws, but are not always able to.

Compared to subsistence adaptation, there is relatively less individual and family adaption to flooding and erosion. Only eight participants mentioned household strategies such as moving possession to accommodate flooding, while 34 (28 from villages) mentioned community-level strategies.

Many ANVs rely on outside help to address flooding and erosion. Help often comes in the form of government-sponsored, consultant-led planning efforts that do not necessarily led to adaptive actions. HMPs, which are developed for many ANVs by the same handful of state and federally sponsored consultants, are a key example. While
HMPs suggest community-level hazard mitigation actions, these are often drawn from a generic, contractor-generated list. The result is that HMPs look surprisingly similar across Alaska, despite the vast array of geography and potential natural hazards. HMPs for 28 villages call for fire avoidance methods, even though this is not a significant problem for many villages. Shishmaref's HMP [83] profiles wildfires as a hazard and suggests 5 fire mitigation actions, although Shishmaref is an island with little vegetation and no record of wildfire. Yet permafrost degradation is not profiled as a hazard, despite the fact (admitted in the HMP) that it is a major contributor to erosion [83, 50].

Other forms of community-level adaptation mentioned by participants include data collection $(\mathrm{n}=31)$, applying for grants for various projects $(n=36)$, education $(n=16)$, political advocacy (i.e., lobbying) $(n=28)$, building capacity to adapt ( $\mathrm{n}=33)$, pursuing renewable of more efficient energy $(n=20)$, promoting community development and wellness $(n=44)$, getting infrastructure to control flooding and erosion $(n=34)$, mitigate other stressors to environment, aside from climate change $(n=8)$, and disaster preparedness measures $(n=25)$. A few ANVs - most notably Newtok, Shishmaref, and Kivalina-have sought to relocate their entire village with government assistance. This approach has been stymied by several factors, including the difficulty of navigating laws related to relocation, community disagreement, and the lack of political will to fund such relocations. [84]

\subsection{Key Differences between Participant Views and the Literature}

The differences between ANV participants and those outside ANVs were not as significant as I had hypothesized. This may be because many of those that I selected for participation from outside of ANVs had interests in facilitating ANV adaptation. Perhaps the most significant difference relates to views on increasing ANV jurisdiction. Of the 24 participants who suggested devolving more programs and decisions to the ANV level, 8 were in ANVs and 18 were Natives. Of the 16 who expressed doubts about increasing ANV jurisdiction, 2 were in ANVs and 4 were Natives. Other differences include the greater focus of ANV participants on subsistence concerns and the greater focus of non-ANV participants on laws, institutions, and planning.

I found more significant differences between views expressed by participants as a whole and views in the literature regarding the need for more data, vulnerability assessments, and planning for climate change [85] [86]. While participants outside ANVs tended to view the process of planning and data collection more favorably than those from ANVs, many participants suggested that there is a need for more meaningful adaptation action (as opposed to just planning and data collection). Also, while there is some law review literature calling for new laws and agencies [46], many participants expressed a lack of faith in laws and a reluctance to create more bureaucracy. 


\subsection{Need for More Holistic View}

Overly narrow views of how government can facilitate adaptation come from failure to understand rapid climate change as just one of many challenges to ANVs, including efforts to colonize, cultural erosion, dependence on Western goods and infrastructure, and limited means of generating revenue [28] [35, 91] [49] [81]. Climate change adaptation measures that ignore these other problems may be insufficient to maintain physical and cultural continuity. For example, government-assisted community relocation accomplishes nothing if residents are not able to generate enough income to remain in the new location. Twenty-seven participants specifically mentioned concern about the lack of village self-sufficiency and long-term sustainability (although I did not ask about self-sufficiency). Forty-four participants (32 ANV participants) referred to adaptation strategies beyond just those related to climate change and natural hazards (i.e., economic development). This suggests that infrastructure and solutions generated and maintained by those outside of villages is not an ideal solution and could be continuing a history of "colonization."

Yet this is exactly what is happening in terms of climate change adaptation measures for flooding, erosion, and disasters. Flooding and erosion control and disaster response measures are typically generated and maintained by outside government entities and consultants who do not take into account food security and the subsistence lifeway. As one FEMA representative noted, "FEMA doesn't do food." FEMA-sponsored HMPs produced for ANVs are limited to an extremely narrow scope of hazards, and none that I reviewed provide mitigation measures for subsistence impacts.

While mitigation measures listed in HMPs often call for integration with other community plans, this seldom occurs. Community level comprehensive plans generally focus on issues that are important to physical and cultural continuity but not directly related to natural hazards and climate change. I only came across a single instance where a community plan and a HMP built on and incorporated each other (Utqiagvik/Barrow). In many cases, village residents do not know that hazard mitigation plans exist. Fifteen ANV participants indicated they were not aware of any community plan, but at least 11 of these villages have their own comprehensive and/or HMP.

\subsection{Need to Avoid Maladaptations}

Particularly with community relocation, there is a potential for maladaptation when adaptation proponents call for adaptation actions that are not needed or unsustainable. By maladaption, I mean adaptation that can have negative consequences for the adapting community in the long term, or for other communities. [85, 7] [86, 407]. Fifty-three participants described maladaptations or unintended consequences they had observed from adaptation measures. Twenty referred to seawalls, 11 referred to infrastructure not suitable for Alaska because it is designed for the contiguous states (the Lower 48), and eight referred to infrastructure that is "overbuilt" for villages and cannot be maintained by local residents.

Another potential maladaptation may be the sense of action that comes from extensive monitoring of coastal erosion levels, without any follow-up action to address the erosion. The U.S. Bureau of Indian Affairs, the U.S. Environmental Protection Agency, and other agencies continue to offer communities grants to monitor impacts and plan for adaptation without offering sufficient funding to implement these plans. Twenty-one participants referred to applying for such grants as a strategy, but it is not clear how these grants, if received, will facilitate adaptation in the long term. Seventeen participants referred to community-led climate change monitoring programs, but it is not clear what will be done with monitoring results.

Millions of dollars have been invested in studies and plans for communities to relocate, with little to show for these efforts besides long reports. Ten participants suggested that too much planning is occurring without follow-up action, and 22 noted challenges in implementing plans. A contrasting example may be the relocation of Nuiqsut residents in 1973. Families from the original site, which had been abandoned, due to school attendance requirements decided to return to the site and live there in tents until infrastructure could be built.

Government resources could be better spent building the leadership and collective action needed to (1) get village buildings out of areas that frequently flood or are close to the shoreline; (2) build infrastructure that can be maintained by local residents; (3) empower villages to participate in political institutions that improve resident access and rights to subsistence foods. Building social capital to support leadership and collective action is an important adaptation measure, whether one is adapting to rapid climate change or other changes. [89, 141] [90, 119] [91]. Thirty-four participants noted problems related to lack of community unity, and 23 referred to leadership problems. Seventy-six participants (half of all participants), including 40 from villages, noted the importance of fostering connections at the village level, between villages, and/or with outside government.

\subsection{Need for New Laws?}

The current laws appear to have less of a role in ANV adaptation than social, economic, and political factors. Only five participants suggested a need for ordinances to shape development with regard to flooding, and only 1 village participant referred to an existing ordinance. This is notable since 17 of the villages from which participants were drawn participant in NFIP and should have ordinances limiting development in floodplains.

Although 80 participants discussed relocation obstacles, only six referred to the lack of a law or agency to coordinate relocation, and only nine referred to the problem of lengthy 
environmental reviews mandated by the U.S. National Environmental Policy Act [92]. Only 17 of the participants who discussed the potential for new laws and agencies suggested a need for a new law or agency to address relocation and/or climate change. This suggests a lack of political will (at more than one level) for sweeping legal changes that could facilitate adaptation. Given the lack of will, along with the State of Alaska's budget deficits, incremental law changes that build on existing institutions may be more achievable.

This does not mean that laws and institutions should ignore climate change adaptation, especially since so many participants see a need for a government role. It does mean that institutions should adjust planning and granting processes to facilitate community-led (as opposed to outside government-led) adaptation measures that can actually be implemented and carried out by ANVs. As suggested by many participants and the literature, measures that increase flexibility and relax rigidity (while still maintaining the rule of law) are likely to facilitate adaptation $[36,837][93,320]$. Ideas offered by participants include mechanisms to ease the transfer of money between agencies that support adaptation; longer terms for agency budgets and for grant recipient; practices that are better adapted to remote Arctic areas (i.e., avoiding Lower 48 building codes); and more deference to ANVs and lower levels of government. These ideas go far beyond the need to address flooding, erosion, and subsistence impacts, suggesting a need for a more holistic view of adaptation.

\section{Conclusions}

It is a daunting task to describe adaptation actions and barriers across an area as large and diverse as Alaska. But this study is important since, for better or worse, the 229 ANVs in this area are uniformly subject to Alaskan laws and institutions that affect adaptation. Further, Alaska is unique compared to any other American state, due to its size, climate, and the remoteness of many settlements. This article is the first of several that I intend to write on how ANVs across the state are adapting, what barriers they face, and how laws, institutions, and planning processes can facilitate adaptation. The emphasis here is on a method that gathers information from a representative number of ANVs (59 in this case) and shows how adaptation needs "on the ground" may differ from what is described or suggested in community plans and literature.

While plans and reports written by consultants and researchers often suggest that there is a need for more data and planning efforts, many ANV participants express frustration with the lack of meaningful adaptation actions and an overly narrow view of adaptation. At the community level, there is a need for more empowerment to adapt to a variety of challenges, from climate change to the difficulty of participating in the Western cash economy. Yet the institutional response is often to fund data collection and plans (such as HMPs) that are unlikely to be implemented, or to erect flooding and erosion barriers and other infrastructure that ANVs cannot maintain on their own. There is a need to shift institutional focus toward helping ANVs implement and sustain efforts to avoid flooding and erosion, along with efforts that improve food security and economic and social wellbeing. In future articles, I will propose relatively inexpensive actions that agencies and communities could take to facilitate adaptation, as well as incremental law changes that could be made across several areas of law to more holistically address adaptation challenges.

\section{Acknowledgements}

This work was made possible by a grant from the National Oceanic and Atmospheric Administration Sectoral Applications Research Program, Grant Number NA16OAR4310122.

\section{Abbreviations}

$\begin{array}{ll}\text { ANV } & \text { Alaska Native Village } \\ \text { FEMA } & \text { Federal Emergency Management Agency } \\ \text { GAO } & \text { U.S. Government Accountability Office } \\ \text { HMP } & \text { Hazard Mitigation Plan }\end{array}$

\section{REFERENCES}

[1] Adger WN, Barnett J. Four reasons for concern about adaptation to climate change. Environ Plan A. 2009; 41(12):2800-5.

[2] Bennett TBB, Cochran P, Gough R, Lynn K, Maldonado J, Voggesser G, et al. Indigenous Peoples, Lands, and Resources. Clim Change Impacts U S Third Natl Clim Assess; Available from:

http://nca2014.globalchange.gov/report/sectors/indigenous-pe oples.

[3] Chapin III FS, Trainor SF, Markon C, Serreze M. Alaska. Clim Change Impacts U S Third Natl Clim Assess. 2014;514-36.

[4] Ristroph EB. Alaska Tribes' Melting Subsistence Rights. Ariz J Envtl Pol. 2010;1:47.

[5] GAO. Alaska Native Villages: Most Are Affected by Flooding and Erosion, but Few Qualify for Federal Assistance. Government Accountability Office; 2003. Report No.: GAO-04-142. Available from:

http://www.gao.gov/products/GAO-04-142

[6] GAO. Alaska native villages: Limited progress has been made on relocating villages threatened by flooding and erosion. Government Accountability Office; 2009. Report No.: GAO-09-551.

[7] Army Corps. Alaska Baseline Erosion Assessment, Study Findings and Technical Report. 2009. 
[8] Indian Law and Order Commission. A Roadmap For Making Native America Safer - Report To The President And Congress Of The United States. 2015. http://www.aisc.ucla.edu/iloc/report/.

[9] 43 U.S.C. $\S \S 1611,1613,1618$.

[10] U.S. Congress, Stafford Act, Pub. L. No. 93-288 (1974), codified as amended at 42 U.S.C. $\S \S 5121-5206$, as amended by Section 322 of the Disaster Mitigation Act of 2000 (P.L. 106-390), Katrina Emergency Management Reform Act of 2006, Pub. L. No. 109-295, 120 Stat. 1394 (codified as amended in scattered sections of U.S.C.).

[11] U.S. Congress, 42 U.S.C. 5133.

[12] Chapin III FS, Folke C, Kofinas GP. A framework for understanding change. In: Chapin III FS, Kofinas GP, Folke C, editors. Principles of Ecosystem Stewardship: Resilience-Based Natural Resource Management in a Changing World. 2009 edition. New York: Springer; 2009. p. 3-28.

[13] Craig RK. "Stationarity is Dead"-Long Live Transformation: Five Principles for Climate Change Adaptation Law. Harv Environ Law Rev. 2010;34(1):9-75.

[14] Field CB, Barros VR, Dokken DJ, Mach KJ, Mastrandrea MD, Bilir TE, et al., editors. Climate Change 2014: Impacts, Adaptation, and Vulnerability, Contribution of Working Group II to the Fifth Assessment Report of the Intergovernmental Panel on Climate Change. Cambridge, United Kingdom and New York, NY, USA: Cambridge University Press; 2014. 1132 p.

[15] Moser SC, Ekstrom JA. A framework to diagnose barriers to climate change adaptation. Proc Natl Acad Sci. 2010 Dec 21;107(51):22026-31.

[16] Walker B, Carpenter S, Andries J, Abel N, Cumming G, Janssen M, et al. Resilience management in social-ecological systems: a working hypothesis for a participatory approach. Conserv Ecol. 2002;6:17 pages.

[17] Moser SC. Navigating the Political and Emotional Terrain of Adaptation: Community Engagement When Climate Change Comes Home. In: Moser SC, Boycoff MT, editors. Successful Adaptation to Climate Change: Linking Science and Policy in a Rapidly Changing World. London: Routledge; 2013. p. 289 305.

[18] Reid MG, Hamilton C, Reid SK, Trousdale W, Hill C, Turner $\mathrm{N}$, et al. Indigenous Climate Change Adaptation Planning Using a Values-Focused Approach: A Case Study with the Gitga'at Nation. J Ethnobiol. 2014;34(3):401-424.

[19] Wildcat DR. Introduction: climate change and indigenous peoples of the USA. Clim Change. 2013 Oct;120(3):509-15.

[20] Abate RS, Kronk Warner EA. Climate Change and Indigenous Peoples: The Search for Legal Remedies. Edward Elgar Pub; 2013. 616 p. Available from:

http://papers.ssrn.com/sol3/papers.cfm?abstract_id=2213506

[21] Chief K, Daigle JJ, Lynn K, Whyte KP. Indigenous experiences in the U.S. with climate change and environmental stewardship in the Anthropocene. 2014 p. 16176. Available from:

http://www.treesearch.fs.fed.us/pubs/46584
[22] Hanna JM. Native Communities and Climate Change: Protecting Tribal Resources as Part of National Climate Policy: Report. 2007; Available from:

http://scholar.law.colorado.edu/cgi/viewcontent.cgi?article $=1$ 014\&context=books_reports_studies

[23] Lynn K, Daigle J, Hoffman J, Lake F, Michelle N, Ranco D, et al. The impacts of climate change on tribal traditional foods. Clim Change. 2013 Oct;120(3):545-56.

[24] Tsosie R. Climate change and indigenous peoples: comparative models of sovereignty. In: Abate RS, Kronk Warner EA, editors. Climate Change and Indigenous Peoples: The Search for Legal Remedies. Edward Elgar Pub; 2013. p. 79-95. Available from:

http://papers.ssrn.com/sol3/papers.cfm?abstract_id=2213506

[25] Berkes F, Jolly D. Adapting to climate change: social-ecological resilience in a Canadian western Arctic community. Conserv Ecol. 2001;5(2):18.

[26] Wuttunee W. Living Rhythms: Lessons in Aboriginal Economic Resilience and Vision. Montréal; Ithaca: Mcgill Queens Univ Pr; 2004. 199 p.

[27] Nakashima DJ, United Nations University, Traditional Knowledge Initiative, Unesco. Weathering uncertainity: traditional knowledge for climate change assessment and adaptation. Paris; Darwin: UNESCO ; UNU-IAS; 2012.

[28] Tobias JK, Richmond CAM. "That land means everything to us as Anishinaabe....": Environmental dispossession and resilience on the North Shore of Lake Superior. Health Place. 2014 Sep;29:26-33.

[29] Brown CL, Knapp C, Trainor SF. Current Coastal Change Projects and Priority Information Needs in Western Alaska, Final Project Report. 2015. Available from: https://accap.uaf.edu/?q=W AK LCC Coastal Change Res earch

[30] Carothers C, Brown C, Moerlein KJ, López JA, Andersen DB, Retherford B. Measuring perceptions of climate change in northern Alaska: pairing ethnography with cultural consensus analysis. Ecol Soc. 2014;19(4). Available from: http://www.ecologyandsociety.org/vol19/iss4/art27/

[31] Chapman RS, Kim S-C, Mark DJ. Storm Damage and Flooding Evaluation Storm-Induced Water Level Prediction Study for the Western Coast of Alaska [Internet]. U.S. Army Corps of Engineers; 2009. Available from: http://www.ariesnonprofit.com/SmithCorpsAKstormSurgeRe port.pdf

[32] Ignatowski JA, Rosales J. Identifying the exposure of two subsistence villages in Alaska to climate change using traditional ecological knowledge. Clim Change. 2013 Nov;121(2):285-99.

[33] Nichols T, Berkes F, Jolly D, Snow NB. Climate change and sea ice: local observations from the Canadian Western Arctic. Arctic. 2004;68-79.

[34] McNeeley SM. Seasons out of balance: Climate change impacts, vulnerability, and sustainable adaptation in interior Alaska. University of Alaska Fairbanks; 2009. Available from: http://www.cakex.org/sites/default/files/project/documents/M cNeeley_Dissertation_2009.pdf. 
[35] Huntington H, Fox S, Berkes F, Krupnik I. The Changing Arctic: Indigenous Perspectives. In: Arctic Climate Impact Assessment - Scientific Report. 2005. p. 62-98.

[36] McNeeley SM. Examining barriers and opportunities for sustainable adaptation to climate change in Interior Alaska. Clim Change. 2012 Apr;111(3-4):835-57.

[37] Huntington $\mathrm{OH}$, Watson A. Interdisciplinarity, native resilience, and how the riddles can teach wildlife law in an era of rapid climate change. Wicazo Sa Rev. 2012;27(2):49-73.

[38] Abate RS, Kronk EA. Commonality Among Unique Indigenous Communities: An Introduction to Climate Change and Its Impacts on Indigenous Peoples. In: Abate RS, Kronk EA, editors. Climate Change and Indigenous Peoples, The Search for Legal Remedies. Edward Elgar Publishing Limited; 2013. p. 3-18.

[39] Kofinas GP, Chapin FS, BurnSilver S, Schmidt JI, Fresco NL, Kielland $\mathrm{K}$, et al. Resilience of Athabascan subsistence systems to interior Alaska's changing climate. Can J For Res. 2010;40(7):1347-1359.

[40] Knapp CN, Chapin III FS, Kofinas GP, Fresco N, Carothers C, Craver A. Parks, people, and change: the importance of multistakeholder engagement in adaptation planning for conserved areas. Ecol Soc. 2014;19(4):16.

[41] Cochran P, Huntington OH, Pungowiyi C, Tom S, Chapin FS, Huntington HP, et al. Indigenous frameworks for observing and responding to climate change in Alaska. Clim Change. 2013 Oct;120(3):557-67.

[42] Loring PA, Gerlach C, Atkinson DE, Murray MS. Ways to help and ways to hinder: Governance for effective adaptation to an uncertain climate. Arctic. 2011;73-88.

[43] Brown CL, Kellie KA, Brinkman TJ, Euskirchen ES, Kielland $\mathrm{K}$. Applications of resilience theory in management of a moose-hunter system in Alaska. Ecol Soc. 2015;20(1). Available from: http://www.ecologyandsociety.org/vol20/iss1/art16/.

[44] Wilson NJ. The Politics of Adaptation: Subsistence Livelihoods and Vulnerability to Climate Change in the Koyukon Athabascan Village of Ruby, Alaska. Hum Ecol. 2014 Feb;42(1):87-101.

[45] Iverson J. Funding Alaska Village Relocation Caused by Climate Change and Preserving Cultural Values During Relocation. Seattle J Soc Just. 2013;12:561.

[46] Bronen R. Climate-induced community relocations: creating an adaptive governance framework based in human rights doctrine. NYU Rev Soc Change. 2011;35:357.

[47] Shearer C. The political ecology of climate adaptation assistance: Alaska Natives, displacement, and relocation. J Polit Ecol. 2012;19:174-183.

[48] Marino E. The long history of environmental migration: Assessing vulnerability construction and obstacles to successful relocation in Shishmaref, Alaska. Glob Environ Change. 2012 May;22(2):374-81.

[49] Loring PA, Gerlach SC, Penn HJ. "Community Work" in a Climate of Adaptation: Responding to Change in Rural Alaska. Hum Ecol. 2016 Feb;44(1):119-28.

[50] Chapin FS, Cochran P. Community Partnership for Self
Reliance and Sustainability, Final Report to Communities from the Alaska Native Science Commission and the University of Alaska Fairbanks. 2014.

[51] Ristroph E. Integrating Community Knowledge into Environmental and Natural Resource Decision-Making: Notes from Alaska and Around the World. Wash Lee J Energy Clim Environ. 2012 Jan 1;3(1):81.

[52] Moller H, Berkes F, Lyver PO, Kislalioglu M. Combining science and traditional ecological knowledge: monitoring populations for co-management. Ecol Soc. 2004;9(3):2.

[53] Burkett M. Indigenous environmental knowledge and climate change adaptation. In: Abate RS, Kronk Warner EA, editors. Climate Change and Indigenous Peoples: The Search for Legal Remedies. Edward Elgar Pub; 2013. p. 96-120. Available from:

http://papers.ssrn.com/sol3/papers.cfm?abstract_id=2213506.

[54] EPA. Climate Change Adaptation Plan. U.S. Environmental Protection Agency; 2014 p. 64. Report No.: EPA 100-K-14-001.

[55] Huntington HP. Observations on the utility of the semi-directive interview for documenting traditional ecological knowledge. Arctic. 1998; 237-242.

[56] Turner NJ, Berkes F. Developing Resource Management and Conservation. Hum Ecol. 2006 Oct 2;34(4):475-8.

[57] Huntington, Henry P. 2000. Using traditional ecological knowledge in science: methods and applications. Ecological Applications. 10(5): 1270-1274.

[58] Trainor SF, Calef M, Natcher D, Chapin FS, McGuire AD, Huntington $\mathrm{O}$, et al. Vulnerability and adaptation to climate-related fire impacts in rural and urban interior Alaska. Polar Res. 2009 Apr;28(1):100-18.

[59] Patton MQ. Qualitative Research \& Evaluation Methods. 3rd edition. Thousand Oaks, Calif.: SAGE Publications, Inc; 2001. $688 \mathrm{p}$.

[60] Creswell JW. Qualitative Inquiry and Research Design: Choosing among Five Approaches. 2nd edition. Thousand Oaks: SAGE Publications, Inc; 2007. 416 p.

[61] Bernard HR, Ryan GW. Analyzing Qualitative Data: Systematic Approaches. 1 edition. Los Angeles Calif.: SAGE Publications, Inc; 2009. 480 p.

[62] Stake RE. Case studies. In: Denzin NK, Lincoln YS, editors. Handbook of Qualitative Research. 2nd edition. Thousand Oaks, Calif: SAGE Publications, Inc; 2000. p. 435-54.

[63] Corbin J, Strauss A. Basics of Qualitative Research: Techniques and Procedures for Developing Grounded Theory. 3rd edition. Los Angeles, Calif: SAGE Publications, Inc; 2007. $400 \mathrm{p}$.

[64] Himes-Cornell A, Kasperski S. Assessing climate change vulnerability in Alaska's fishing communities. Fish Res. 2015 Feb;162:1-11.

[65] Smith LT. Decolonizing Methodologies: Research and Indigenous Peoples. 2 edition. London: Zed Books; 2012. 240 p. 
[66] Miles MB, Huberman AM. Qualitative Data Analysis: An Expanded Sourcebook, 2nd Edition. 2nd edition. Thousand Oaks: SAGE Publications, Inc; 1994. 352 p.

[67] Bernard HR. Research methods in anthropology: qualitative and quantitative approaches. 4th ed. Lanham, MD: AltaMira Press; 2006. 803 p.

[68] Lane MB. Participation, Decentralization, and Civil Society: Indigenous Rights and Democracy in Environmental Planning. J Plan Educ Res. 2003 Jun 1;22(4):360-73.

[69] Schwartz MR, Bridger JC, Hyman D. A Validity Assessment of Aggregation Methods for Multiple Key Informant Survey Data. Community Dev Soc J. 2001;32(2):226-237.

[70] Focht W, Trachtenberg Z. A Trust-Based Guide to Stakeholder Participation. In: Sabatier PA, Focht W, Lubell $M$, Trachtenberg Z, Vedlitz A, Matlock M, editors. Swimming Upstream: Collaborative Approaches to Watershed Management. Cambridge, Mass: The MIT Press; 2005. p. 85135 .

[71] Innes JE, Gruber J, Neuman M, Thompson R. Coordinating growth and environmental management through consensus building. CPS Report: A Policy Research Program Report. Berkeley: California Policy Seminar, University of California; 1994.

[72] Tongco MDC. Purposive Sampling as a Tool for Informant Selection. 2007. Available from:

http://scholarspace.manoa.hawaii.edu/handle/10125/227.

[73] Jacobs MB, Brooks JJ. Alaska Native Peoples and Conservation Planning: A Recipe for Meaningful Participation. Native Stud Rev. 2011;20(2):91-135.

[74] Mack N, Woodsong C, MacQueen K, Guest G, Namey E. Qualitative Research Methods, A Data Collector's Field Guide. Family Health International; 2005.

[75] Cho JY, Lee E-H. Reducing confusion about grounded theory and qualitative content analysis: similarities and differences. Qual Rep. 2014;

[76] Ryan GW, Bernard HR. Data Management and Analysis Methods. In: Denzin NK, Lincoln YS, editors. Handbook of Qualitative Research. 2nd edition. Thousand Oaks, Calif: SAGE Publications, Inc; 2000. p. 769-802.

[77] Silverman D. Analyzing Talk and Text. In: Denzin NK, Lincoln YS, editors. Handbook of Qualitative Research. 2nd edition. Thousand Oaks, Calif: SAGE Publications, Inc; 2000. p. 821-35.

[78] Bixler RP. The political ecology of local environmental narratives: Power, knowledge, and mountain caribou conservation. J Polit Ecol. 2013;20:273-285.

[79] Zhang Y, Wildemuth BM. Qualitative Analysis of Content By. Analysis. 2005;1(2):1-12.
[80] Bertaux S. From the life-history approach to the transformation of sociological practice. In: Bertaux D, editor. Biography and society: The life history approach in the social sciences. London; 1981. p. 29-45.

[81] Cameron ES. Securing Indigenous politics: A critique of the vulnerability and adaptation approach to the human dimensions of climate change in the Canadian Arctic. Glob Environ Change. 2012;22(1):103-114.

[82] U.S. Congress, 43 U.S.C. § 1621(f); 16 U.S.C. § 3192.

[83] Shishmaref Hazard Mitigation Plan. 2015.

[84] Ristroph EB. When Climate Takes a Village: Legal Pathways Toward the Relocation of Alaska Native Villages. Climate Law (forthcoming).

[85] Alaska Climate Change Sub-Cabinet. Alaska's Climate Change Strategy: Addressing Impacts in Alaska." Final Draft Report by the Adaptation Advisory Group. 2010. http://www.tribesandclimatechange.org/documents/nccc/nccc 20110516_328.pdf.

[86] Council on Climate Preparedness and Resilience. Priority Agenda Enhancing the Climate Resilience of America's Natural Resources. 2014

[87] Verschuuren J. Introduction. In: Research Handbook on Climate Change Adaptation Law. Cheltenham, UK: Edward Elgar Pub; 2013. p. 1-15.

[88] Nelson DR, Adger WN, Brown K. Adaptation to Environmental Change: Contributions of a Resilience Framework. Annu Rev Environ Resour. 2007 Nov;32(1):395419.

[89] Norris F, Stevens S, Pfefferbaum B, Wyche K, Pfefferbaum R. Community Resilience as a Metaphor, Theory, Set of Capacities, and Strategy for Disaster Readiness. Am J Community Psychol. 2008;41(1):127-150.

[90] Folke C, Chapin III FS, Olsson P. Transformations in Ecosystem Stewardship. In: Chapin III FS, Kofinas GP, Folke C, editors. Principles of Ecosystem Stewardship: Resilience-Based Natural Resource Management in a Changing World. 2009 edition. New York: Springer; 2009. p. 103-25.

[91] Magis K. Community Resilience: An Indicator of Social Sustainability. Soc Nat Resour. 2010 Apr 5;23(5):401-16.

[92] U.S. Congress, 42 U.S.C. § 4332(C).

[93] Chapin III FS, Kofinas GP, Folke C, Carpenter SR, Olsson P, Abel N, et al. Resilience-Based Stewardship: Strategies for Navigating Sustainable Pathways in a Changing World. In: Chapin III FS, Kofinas GP, Folke C, editors. Principles of Ecosystem Stewardship: Resilience-Based Natural Resource Management in a Changing World. 2009 edition. New York: Springer; 2009. p. 319-38. 